\title{
Competitiveness Analysis of Indonesian Fishery Products in The ASEAN and Canada Markets
}

\author{
Estu Sri Luhur ${ }^{1}$, Sri Mulatsih², Eka Puspitawati ${ }^{3}$
}

\begin{abstract}
This study aimed to analyze the competitiveness of Indonesian fishery products in the ASEAN and Canada markets. The method used was Revealed Comparative Advantage (RCA), Export Product Dynamic (EPD), and X-Model product export potential. The research showed that Vietnam and Canada had a similar level of export structure to Indonesia in the ASEAN market so that Indonesia would have a high competition with both countries. Indonesian fishery products showed a high competitiveness in the export destination markets, except Philippines and Canada. The market position of Indonesian fishery products in Philippines, Thailand and Canadian markets was in the rising star and lost opportunity. These countries also showed as an optimist and potential market for Indonesian fishery products. The policy implication is that government and private sector need to prioritize the export of fishery products to Thailand, Philippines and Canada by improving the product competitiveness through quality improvement and production cost efficiency.
\end{abstract}

Keywords: export, fishery products, competitiveness, X-model product export potential

\begin{abstract}
Abstrak
Penelitian ini bertujuan untuk menganalisis daya saing produk perikanan Indonesia di pasar ASEAN dan Kanada. Metode yang digunakan Revealed Comparative Advantage (RCA), Export Product Dynamic (EPD), dan X-Model product export potential. Hasil penelitian menunjukkan bahwa Vietnam dan Kanada memiliki tingkat kesamaan struktur ekspor dengan Indonesia di pasar ASEAN sehingga Indonesia menghadapi persaingan tinggi dengan kedua negara. Produk perikanan Indonesia menunjukkan daya saing kuat di pasar tujuan ekspor, kecuali Filipina dan Kanada. Posisi pasar produk perikanan Indonesia di pasar Filipina, Thailand dan Kanada berada pada posisi rising star dan lost opportunity. Hasil penelitian juga menunjukkan bahwa Thailand, Filipina dan Kanada sebagai pasar optimis dan potensial bagi produk perikanan Indonesia. Implikasi kebijakan adalah pemerintah dan swasta perlu memprioritaskan ekspor produk perikanan ke Thailand, Filipina dan Kanada dengan meningkatkan daya saing produk melalui perbaikan kualitas dan efisiensi biaya produksi.
\end{abstract}

Kata Kunci: ekspor, produk perikanan, daya saing, model-X produk ekspor potensial

\section{How to Cite:}

Luhur, E. S., Mulatsih, S., \& Puspitawati, E. (2019). Competitiveness Analysis of Indonesian Fishery Products in The ASEAN and Canada Market. Signifikan: Jurnal Ilmu Ekonomi. Vol. 8 (1): 105 - 120. doi: http://dx.doi. org/10.15408/sjie.v8i1.7301. 


\section{Introduction}

Indonesia is one of the biggest maritime nations in the world. Indonesian water territorial is very extensive with an area of 6.32 million $\mathrm{km} 2$ and $99.093 \mathrm{~km}$ of coastline (Ministry of Marine Affairs and Fisheries, 2015). Indonesian waters have huge fishery potential. The United Nations Development Program (UNDP) mentioned that Indonesia waters were a habitat for $76 \%$ of world coral reefs and $37 \%$ of world reef fish. The potential of Indonesian fishery in 2016 was 12.5 tons per year with the value of marine resources and services gained US\$2.5 trillion per year. Due to this condition, the marine and fishery sector had a comparative advantage for Indonesia which was very dependent on the sectors that utilized its natural resources (Oktaviani et al., 2008).

Other than to meet domestic demand, Indonesian fishery production was also used to meet the demand from other countries through export activities. The performance of Indonesian fishery export during 2011-2015 showed the growth of export value. The value of Indonesian fishery export showed growth of 2.29\% per year from US\$3521.091 million in 2011 to US\$ 3,943.935 million in 2015. However, the export volume of fishery products in the same period showed a decrease of $3.41 \%$ per year, from $1,159.35$ thousand tons to 974.55 thousand tons. The decreased export volume was due to lower shrimp exports $(23 \%)$ and fish $(6 \%)$ to the primary destination markets such as the US, Japan, and the European Union (Statistics Indonesia, 2015).

Problems encountered such as the competitiveness of Indonesian fishery products that was still low compared to the competitor countries. Indonesia was recognized as the world's second largest fishing producer after China and the world's third largest aquaculture producer after China and India (Food and Agriculture Organization, 2015). However, Indonesia only occupied the top 10 positions as fishery products exporter in the world. This condition was caused by the low export value of Indonesian fishery products in the international market. The importance of export product competitiveness was driven by the globalization which created a more dynamic and competitive market (Asmara et al., 2016).

The low competitiveness of export commodities from the fishery sector was due to the domination of products with low value-added making it difficult to compete with products from other countries (Kusumastanto, 2008). The huge dominance of fresh/chilled fish caused a low value-added so that the comparative advantage and competitiveness of Indonesian fishery products was low (Saptanto, 2011). This phenomenon had raised a challenge for Indonesia to maintain or seize the international market share. Therefore, a key which must be properly addressed so that the Indonesian marine and fishery sector could win the global competition was the improvement of competitiveness (Chasanah et al., 2017).

Data from the Ministry of Marine Affairs and Fisheries (2015) showed that the leading export commodities were shrimp and lobster and tuna which tended to be low value-added. The export destinations of this leading commodities were dominated by the United States, Japan, and European Union markets as the developed country group. The facts showed that the contribution of the primary destination countries tended to decline, especially Japan and the EU. The economic crisis that hit those three countries significantly affected the 
performance of the Indonesian fishery product trade. To maintain the export performance, it was necessary to develop the markets in other countries. This open opportunity was created due to the many cooperation or economic integration among countries (Suci et al., 2015).

This problem encouraged the government to promote market diversification to the non-traditional area with bigger economic and trade opportunity. One of the market opportunities was the Free Trade Agreement (FTA) between ASEAN and Canada initiated by Canada in 2016. The opportunity for Indonesia was that Canada becoming the new market for Indonesian fishery products in addition to the existing traditional markets. Ningsih \& Kurniawan (2016) stated that ASEAN's market role was very important to Indonesia, especially for most products with comparative advantages such as fishery products. However, this agreement became a threat to Indonesia because Indonesia would be a market for Canada's fishery products. This due to the following challenge from this free trade agreement which was to open the Indonesian economic gradually (Widyastutik et al., 2014).

Previous studies measured the competitiveness of Indonesian fishery product commodities by RCA and EPD methods. However, studies with X-Model methods to measure market potential for Indonesia's fishery product exports were very limited. In FTA scheme followed by Indonesia, most of the existing studies focused on the FTAs conducted between Indonesia and the trading partner countries. This study analyzed the FTA between Indonesia in the ASEAN region and Canada which was in the initiation stage since 2016. Therefore, this study was

conducted to measure the competitiveness position and market development strategy which focused on Indonesian fishery products in ASEAN and Canada markets.

\section{Methods}

This study used secondary data which was annual data between 2010 up to 2015 consisted of countries as the export destination markets in ASEAN-Canada FTA, which were 6 countries. All the data of export value of Indonesian fishery product to ASEAN countries (Malaysia, Philippines, Singapore, Thailand, Vietnam) and Canada was obtained from the United Nations Commodity Trade based on Harmonized System (HS) codes of 4 digits, 1996 version. Fishery commodity groups analyzed were: a) HS 0301 for live fish; b) HS 0302 for fresh/chilled fish; c) HS 0303 for frozen fish; d) HS 0304 for fillet and fish meat; e) HS 0305 for dried/salted/smoked fish; f) HS 0306 for the crustaceans; and g) HS 0307 for the molluscs.

This research used Revealed Comparative Advantage (RCA) method to measure competitiveness fishery product of Indonesia. RCA method was used to determine the comparative superiority or competitiveness of a commodity. RCA was an index that measure the export performance of a commodity from a country by evaluating the export role of the commodity that showed the ratio between market share of a certain country's commodity in the global market with exports share if the country toward the total of world export (Zuhdi \& Suharno, 2015). Based on Bender \& Li (2002), the RCA index considered intrinsic benefit of certain exports commodity with the change of productivity in a productivity economic and the relative grace factor. 
RCA assumption is the pattern of commodity trading reflecting the differences of each country related to relative cost and non-price factor. So that RCA could reveal comparative superiority from those countries in international trading. If RCA value was bigger than 1 , the product had comparative superiority or strong competitiveness. Otherwise, if RCA value is smaller than one, the product did not have comparative superiority or weak competitiveness. Systematically, the calculation method of RCA as followed (Kanaka \& Chinadurai, 2012).

$$
\operatorname{RCA}_{i}^{j}=\frac{X_{i}^{j} / X_{t}^{j}}{X_{i}^{w} / X_{t}^{w}}
$$

Where:

$R C A_{i}^{j}=$ competitiveness of Indonesian fishery product to export destination country

$X_{i}^{j} \quad=$ value of Indonesian fishery product export in export destination country

$X_{t}^{j} \quad=$ value of total export of Indonesia in exports destination country

$X_{i}^{w} \quad=$ value of world fishery product export in export destination country

$X_{t}^{w} \quad=$ value of total world export in export destination country

This study also used the Export Product Dynamic (EPD) method as one of the indicators that can give good depiction about competitiveness level. The indicator measured market position from a country's product for certain market destination. An EPD matrix consisted of market appeal and business strength information. Combination of market appeal and business strength resulted in position character of product that wanted to analyze in four categories. There are "Rising Star", "Falling Star", "Lost Opportunity", and "Retreat" seen in Figure 1.

Figure 1. Market appeal and business strength in EPD matrix

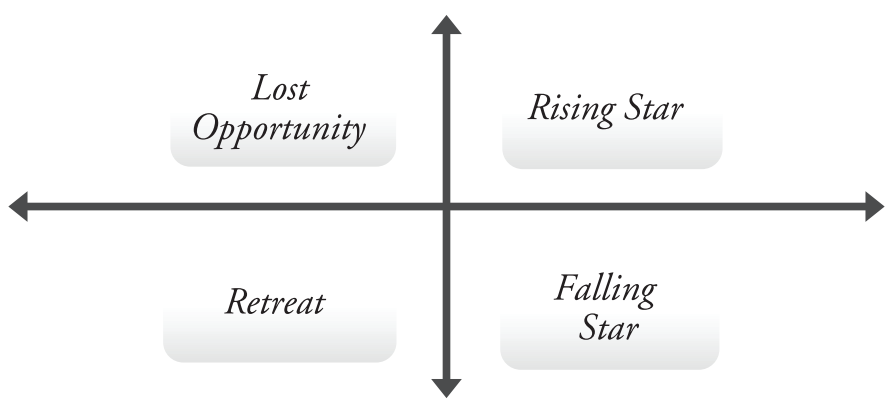

Sources: Estherhuizen (2006)

The estimated commodity of competitiveness position would place one of four quadrants depended on market appeal and business strength of the commodity. The general formula of EPD as followed (Hasibuan et al., 2012):

$\mathrm{X}$ Axis : the growth of export market appeal $=$

$\frac{\sum_{t=1}^{T}\left[\left(\frac{X_{i j}}{W_{i j}}\right)_{t} \times 100 \%-\left(\frac{X_{i j}}{W_{i j}}\right)_{t-1} \times 100 \%\right]}{T}$ 
Y Axis: the growth of product market appeal =

$$
\frac{\sum_{t=1}^{T}\left[\left(\frac{X_{t}}{W}\right)_{t} \times 100 \%-\left(\frac{X_{t}}{W}\right)_{t-1} \times 100 \%\right]}{T}
$$

Where:

$X_{i j}=$ value of Indonesian fishery product in export destination country

$X_{t}=$ value of Indonesian total export in export destination country

$W_{i j}=$ value of world fishery product export in export destination country

$W_{t}=$ value of world total export in export destination country

$t=$ year $-\mathrm{t}$

$T=$ analysis number of year to use

To determine market development potential in each ASEAN country and Canada, this study used the X-Model of Potential Export Product method. This method was used to conduct product clustering that had high development potential in export destination country by considering competitiveness (RCA and market position (EPD). X-Model of potential export product method was shown in Figure 2.

Figure 2. X-Model of potential export product

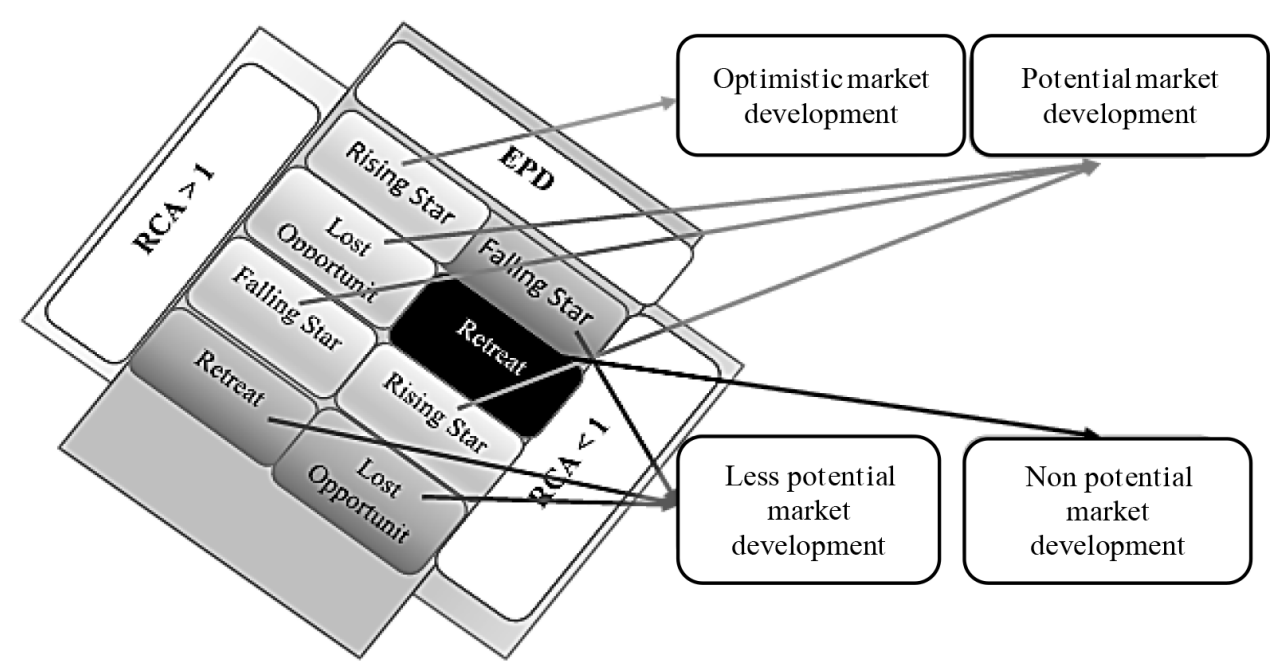

\section{Result and Discussion}

Marine resources potential made Indonesia as one of the countries of the producer of fishery products in the world. Total of production amounted 22.4 million ton in 2016 that consisted of capture fisheries of 6.83 million ton and aquaculture was 16.68 million ton. The fishery production had increased better than in 2015 that was amounted $0.42 \%$ (Ministry of Marine Affairs and Fisheries, 2017). The trend of Indonesian fishery production had increased since 2012 with the average enhancement of 20.9 million ton in the same period. The development of Indonesian fishery production can be seen in Figure 3. 
Figure 3. Indonesian fisheries production

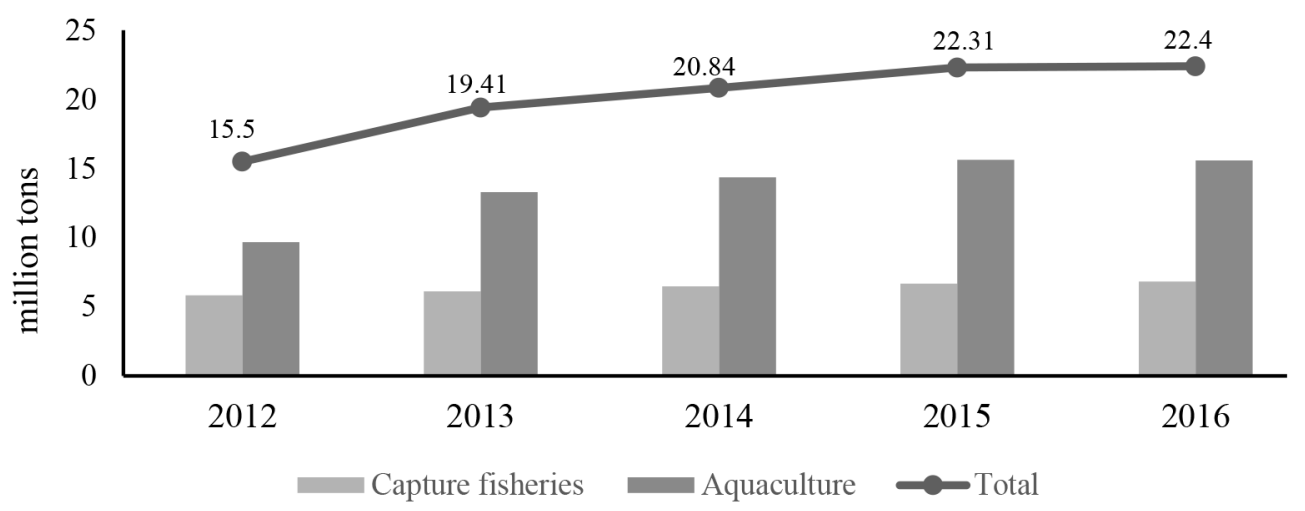

Source: Ministry of Marine Affairs and Fisheries (2017)

The fishery production was utilized to fulfill the consumption of the country. The compliance of the country's fish consumption really depended on the stock of fish supply. Data of fish supply was to find out the number of fish which were available to fulfill domestic consumption needs as it was shown in Table 1 . Table 1 showed the trend of fish supply and consumption per capita in 2011-2015, respectively showed an average growth of $10.15 \%$ and $6.26 \%$. Table 1 also showed that fish stock in the country was still surplus so fish consumption needed to increase and export needed to enhance to permeate country's fishery production.

Table 1. Stock and Fisch Consumption in 2011-2015

\begin{tabular}{|c|c|c|c|c|c|c|c|c|}
\hline & \multirow[b]{2}{*}{ Details } & \multirow[b]{2}{*}{2011} & \multirow[b]{2}{*}{2012} & \multirow[b]{2}{*}{2013} & \multirow[b]{2}{*}{2014} & \multirow[b]{2}{*}{2015} & \multicolumn{2}{|c|}{ Growth (\%) } \\
\hline & & & & & & & $\begin{array}{l}2011 \text { - } \\
2015\end{array}$ & $\begin{array}{l}2014- \\
2015\end{array}$ \\
\hline \multirow[b]{2}{*}{ Fish stock } & Total (1,000 tons) & 10,282 & 11,588 & 11,882 & 13,072 & 15,978 & 11.65 & 22.23 \\
\hline & $\begin{array}{l}\text { Per capita } \\
\text { (kg/cap/year) }\end{array}$ & 42.49 & 47.22 & 47.77 & 51.80 & 62.55 & 10.15 & 20.75 \\
\hline $\begin{array}{c}\text { Fish } \\
\text { consumption }\end{array}$ & $\begin{array}{l}\text { Per capita } \\
\text { (kg/cap/year) }\end{array}$ & 32.25 & 33.89 & 35.21 & 38.14 & 41.11 & 6.26 & 7.79 \\
\hline Deviation & $\begin{array}{l}\text { Per capita } \\
\text { (kg/cap/year) }\end{array}$ & 10.24 & 13.33 & 12.56 & 13.66 & 21.44 & 20.29 & 56.95 \\
\hline
\end{tabular}

Sources: Ministry of Marine Affairs and Fisheries (2015)

The production of capture fisheries and aquaculture were then export to trading partners country of Indonesia. Based on goods group in Harmonized System (HS) 4 digits, Indonesia fishery product was categorized from live fish (HS 0301), fresh/chilled fish (HS 0302), frozen fish (HS 0303), fillet and fish meat (HS 0304), dried/salted/smoked fish (HS 0305), crustaceans (HS 0306) and molluscs (HS 0307. The performance export for these fishery products from 2012 until 2016 shows in Table 2. 
Estu Tri Luhur

Competitiveness Analysis of Indonesian Fishery Products

Table 2. Performance Export of Indonesian Fishery Products Based on 4 Digit HS

\begin{tabular}{|c|c|c|c|c|c|}
\hline \multirow{2}{*}{ Fishery products } & \multicolumn{5}{|c|}{ Volume (tons) } \\
\hline & 2012 & 2013 & 2014 & 2015 & 2016 \\
\hline Live fish & 1,106 & 17,083 & 17,094 & 11,094 & 9,767 \\
\hline Fresh/chilled fish & 9,183 & 98,218 & 68,006 & 67,268 & 58,895 \\
\hline Frozen fish & 431,045 & 425,807 & 415,343 & 210,435 & 213,791 \\
\hline Fillet and fish meat & 90,677 & 81,220 & 88,199 & 95,430 & 95,523 \\
\hline Dried/salted/ smoked fish & 23,880 & 17,267 & 17,364 & 16,244 & 13,823 \\
\hline Crustaceans & 137,778 & 145,662 & 160,939 & 152,677 & 164,308 \\
\hline Molluscs & 95,788 & 98,698 & 93,475 & 115,447 & 131,716 \\
\hline Total & 789,457 & 883,955 & 860,479 & 668,595 & 687,822 \\
\hline \multirow{2}{*}{ Fishery products } & \multicolumn{5}{|c|}{ Value (US\$ thousand) } \\
\hline & 2012 & 2013 & 2014 & 2015 & 2016 \\
\hline Live fish & 60,555 & 63,413 & 59,273 & 60,333 & 70,128 \\
\hline Fresh/chilled fish & 206,280 & 179,172 & 149,972 & 171,824 & 129,359 \\
\hline Frozen fish & 519,856 & 466,889 & 407,528 & 329,170 & 388,913 \\
\hline Fillet and fish meat & 423,213 & 384,058 & 413,555 & 430,697 & 427,299 \\
\hline Dried/salted/ smoked fish & 126,372 & 80,800 & 77,808 & 60,794 & 62,188 \\
\hline Crustaceans & $1,206,544$ & $1,481,284$ & $1,815,230$ & $1,356,323$ & $1,464,399$ \\
\hline Molluscs & 210,252 & 200,739 & 188,110 & 249,498 & 358,317 \\
\hline Total & $2,753,072$ & $2,856,355$ & $3,111,926$ & $2,658,638$ & $2,900,604$ \\
\hline
\end{tabular}

Source: United Nations Commodity Trade, 2017 (processed)

If it was seen from the volume side, the performance of Indonesian fishery product export decreased $3.39 \%$ in 2012-2016, that 789, 457 tons became 687,822 tons. The decrease in the export volume was encouraged by the export volume decrease of frozen fish (HS 0303) and dried/salted/smoked fish (HS 0305) that were $16.08 \%$ and $12.78 \%$. As it was in Table 2, the export volume of both fish commodities continued to decrease from 2012 until 2016. For frozen fish, the biggest reduction export occurred in 2015 that was amounted $49.34 \%$ worse than in 2014. For dried/salted/smoked fish commodity, export performance had the biggest reduction in 2013 of $27.69 \%$.

If it was seen from each commodity contribution toward the value of fishery product export, crustaceans (HS 0306) became the biggest contributor with US\$ 1.46 billions or $50.49 \%$ from the total value of Indonesian fishery export in 2016. The second and third grade were given by fillet and fish meat (HS 0304) amounted US\$ 427 million (14.73\%) and frozen fish (HS 0303) was US\$ 389 million (13.41\%). In 2016, frozen fish and crustaceans products had export value growth rather than in 2015 respectively of $18.15 \%$ and $7.97 \%$. Meanwhile, value export of fish fillet and fish meat had a reduction of $0.79 \%$. 
One of opportunity in developing market export destination of the fishery is by cooperating with ASEAN and Canada. The economic relation between ASEAN and Canada have been held since 1977. Trade volume of both parties shows the enhancement every year. This positive sign encouraged ASEAN and Canada to reveal Joint Declaration Between ASEAN and Canada on Trade and Investment (JDTI) in order to encourage and increase economic cooperation. This cooperation showed the significant result in which the trade volume of ASEAN and Canada in 2013 achieved almost CAD17 billion o increased 7.3\% from 2012. Furthermore, adding the term of agreement from 2016 - 2020 regenerated the agreement. In 2017, Canada and ASEAN had the plan to make FTA together so that the economic activity of both parties could be more integrated.

Trade performance of both parties continued to grow rapidly in years. In 2015, trade in bilateral goods between ASEAN and Canada achieved 21.4 billion dollars in Canada or it increased better than in 2014 that was only 18.2 billion dollars in Canada. The data showed that trade volume between both of then increased $10 \%$ every year in the period of last 5 years. The magnitude of the trade showed that ASEAN had a contribution of $2.02 \%$ from total trade of bilateral goods of Canada was bigger than Germany $(1.97 \%)$ as the sixth biggest trading partner of Canada.

Figure 4. Export of Indonesian Fishery Products to ASEAN and Canada

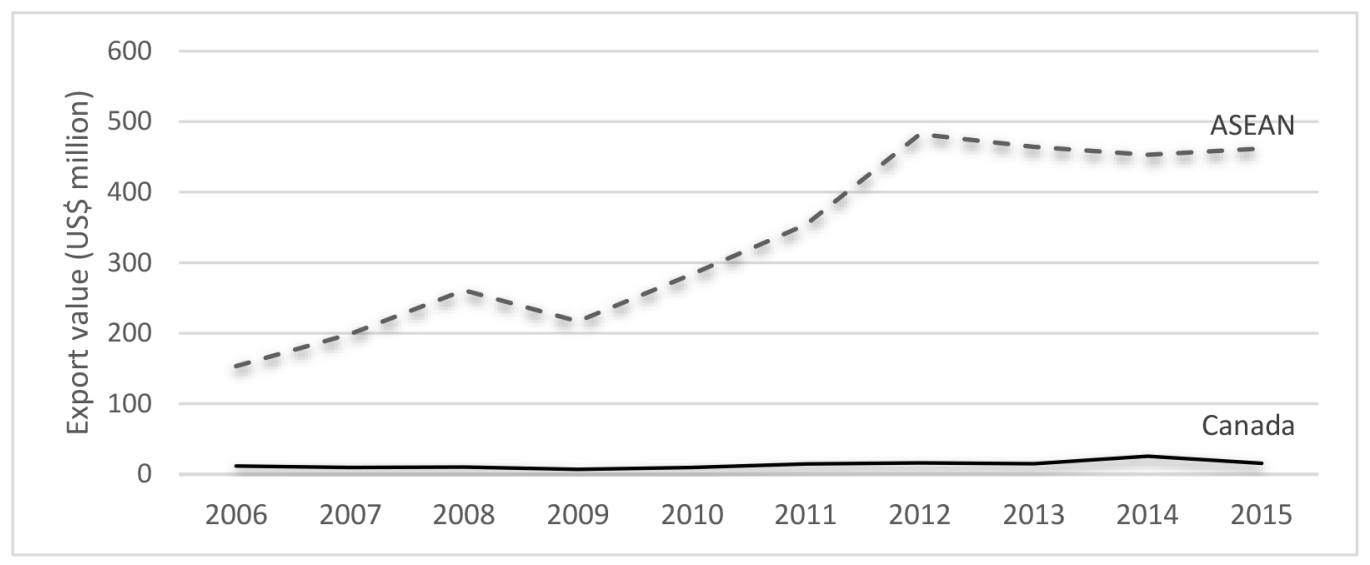

Source: United Nations Commodity Trade, 2017 (processed)

FTA schematic also impacted the performance of Indonesian fishery product export to ASEAN and Canada markets in the last 10 years. The exports development of Indonesian fishery product to ASEAN and Canada is showed in Figure 4. Export development to ASEAN grew in average 12\% in 2006-2010 and 5\% in 2011-2015. Exports performance of Indonesian fishery product to Canada downed in the average of $4 \%$ per year in 20062010, but it increased becoming 1\% per year in 2011-2015. This trade performance showed promising potential from higher economic integration, whether integration with ASEAN countries or between regions integration.

Canada has FTA with ASEAN that plays an important role in facing the United State and its foreign policy. Other than that, the cooperation is also to face the resurrection 
economic of China and uncertainty of Uni Europe countries. Therefore, the Foreign Affairs Ministry of Canada in 2016 announced that feasibility study would be conducted to find out the opportunity and challenge of the free trade agreement formation ASEAN and Canada in the future. If FTA is conducted successfully, FTA will have a big potential of economic cooperation at large. It means, it is for ASEAN and Canada, it is also to improve the position of Canada business so that integration with intra-ASEAN to be more intends.

Exports structure of Indonesian fishery product in ASEAN market was dominated by frozen fish of 40\%, fresh/chilled fish (20\%) and crustaceans (14\%) in 2010-2015. The similar export structure was shown by competitors country of Indonesia, which were Vietnam and Canada. Superiority fishery product of Vietnam was fish fillet that gave a contribution of $60 \%$ and the rest was donated by crustaceans and mollusks groups of 20\%. Meanwhile, Canada showed the most same with Indonesia in which frozen fish gave the biggest contribution (40\%) and it was followed by crustaceans and fillet and fish meat products with the contribution of $15 \%$ and $13 \%$. These facts were shown with the calculation result of the Export Similarity Index (ESI) between Indonesia and five trading partners in ASEAN market in Table 3.

Table 3. The average Value of Export Similarity Index (ESI) for Fishery Product between Indonesia and Trade Partners in ASEAN Market in 2010-2015

\begin{tabular}{cccccc}
\hline \multirow{2}{*}{ Products } & \multicolumn{5}{c}{ Trading Partner } \\
\cline { 2 - 5 } & Malaysia & Singapore & Thailand & Vietnam & Canada \\
\hline Live Fish & 0.028 & 0.003 & 0.006 & 0.006 & 0.000 \\
Fresh/chilled fish & 0.036 & 0.009 & 0.041 & 0.002 & 0.007 \\
Frozen fish & 0.073 & 0.025 & 0.055 & 0.213 & 0.431 \\
Fillet and fish meat & 0.018 & 0.010 & 0.020 & 0.130 & 0.130 \\
Dried/salted/smoked fish & 0.013 & 0.009 & 0.020 & 0.020 & 0.003 \\
Crustaceans & 0.152 & 0.010 & 0.126 & 0.152 & 0.152 \\
Molluscs & 0.067 & 0.019 & 0.039 & 0.119 & 0.119 \\
\hline ESI & 0.388 & 0.085 & 0.308 & 0.642 & 0.842 \\
\hline
\end{tabular}

Note: Philippines was not analyzed because there were no data

Source: United Nations Commodity Trade, 2017 (processed)

Export similarity index (ESI) has a value between zero and one or $0 \leq S \leq 1$. ESI value that closes to zero shows the export structure of both countries is not the same. It means, very slight competition causes the loss of market share because of the same product. Otherwise, ESI value that closes or the same as 1 (one) marks that pattern or structure exports of both countries is the same (or close to identical) so that both countries face strong rivalry that will cause the loss of market share in export destination country (Finger \& Kreinin, 1979).

Table 3 shows the ESI calculation between Indonesia and trading partners in ASEAN markets in 2010-2015. ESI result indicates that trading partners that have a similarity of 
high fishery product export are Canada and Vietnam in which ESI value is reported bigger than 0.50. Canada is the highest similarity level of export structure with the ESI value of 0.842 . The country that is the main competitor of Indonesia is Vietnam with an ESI value of 0.642. This condition is because of the enhancement of export structure similarity of main competitor countries significantly every year during 2010-2015 (Table 4).

In fact, Vietnam showed the export structure of fishery product that is really the same as Indonesia at the end of the period that was amounted 0.74 in the previous year. The same condition occurred to Canada at the end of the period that reported ESI value was 0.942 toward Indonesia. This condition became the warning for Indonesia that will compete to Canada and Vietnam in the future in maintaining market share for fishery product in the ASEAN market. Thus, Indonesia has to work hard to increase competitiveness fishery product to face rivalry in the future.

Table 4. Value of Export Similarity Index (ESI) for fishery products of Indonesia and Trading Partners in ASEAN Market

\begin{tabular}{cllllll}
\hline \multirow{2}{*}{ Trading partners } & \multicolumn{7}{c}{ ESI Value } \\
\cline { 2 - 7 } & 2010 & 2011 & 2012 & 2013 & 2014 & 2015 \\
\hline Malaysia & 0.325 & 0.345 & 0.396 & 0.381 & 0.350 & 0.387 \\
Singapore & 0.086 & 0.066 & 0.074 & 0.079 & 0.083 & 0.121 \\
Thailand & 0.271 & 0.269 & 0.353 & 0.249 & 0.332 & 0.317 \\
Vietnam & 0.368 & 0.409 & 0.637 & 0.643 & 0.740 & 1.000 \\
Canada & 0.546 & 0.650 & 0.743 & 0.906 & 0.936 & 0.942 \\
\hline
\end{tabular}

Source: United Nations Commodity Trade, 2017 (processed)

On the other side, the country that had a different export structure of fishery product was Singapore that was shown by the low ESI value of 0.085. It means the Export structure of Indonesia and Singapore fishery product were really different. It was because of the low absolute superiority of Singapore due to overflowing fishery source that occurs in the main export commodity. The low level of similarity export was also shown by Malaysia and Thailand with an ESI value of 0.3888 and 0.308 . Both countries had ESI value that tent to decrease during 2010-2015. It showed that Malaysia and Thailand had a different export structure of fishery product from Indonesia. It meant, the specification of the fishery product level of three countries in the ASEAN market increased and the trade relation of three countries was complimentary (Wang \& Liu, 2015).

Based on United Nations Commodity Trade, it is obtained that in 2010-2015, there were 7 commodity groups of Indonesia fishery in HS 4 digits had strong competitiveness with RCA index value RCA > 1 that were different in each export destination country. Table 5 shows the estimation result of Indonesia fishery product competitiveness in ASEAN and Canada during the period 2010-2015 with RCA method. 
Table 5. RCA Estimation Result of Indonesia Fishery Product in ASEAN and Canada Market

\begin{tabular}{lcccccc}
\hline \multicolumn{1}{c}{ Commodity } & Malaysia & Philippines & Singapore & Thailand & Vietnam & Canada \\
\hline Live fish & 6,59 & 14,26 & 2,74 & 3,16 & 13,61 & 7,61 \\
Fresh/chilled fish & 9,70 & 0,06 & 6,18 & 1,73 & 1,23 & 0,30 \\
Frozen Fish & 0,71 & 0,10 & 1,64 & 2,58 & 3,10 & 0,86 \\
Fillet and fish meat & 3,70 & 0,38 & 1,92 & 2,55 & 4,81 & 3,24 \\
Dried/salted/ smoked fish & 1,31 & 0,17 & 2,09 & 1.65 & 2,39 & 0,46 \\
Crustaceans & 1,31 & 1,21 & 1,65 & 0,65 & 2,14 & 8,40 \\
Molluscs & 1,04 & 0,08 & 0,98 & 0,79 & 2,66 & 4,22 \\
\hline
\end{tabular}

Source: United Nations Commodity Trade, 2017 (processed)

RCA estimation results in Table 5 shows that comparative superiority of all Indonesia fishery product had strong competitiveness $(\mathrm{RCA}>1)$ in Vietnam market, otherwise, most Indonesian fishery products had low competitiveness in Philippines market. Through the RCA value can be seen that the competitiveness of Indonesian live fish had strong competition in all the export destination markets because RCA value was bigger than 1 . It showed that the strongest competitiveness among six export destination countries was the Philippines, followed by Vietnam and Canada. This result indicated that the market share of Indonesian fishery product export was bigger than other exporter countries (Serin \& Civan, 2008).

Improving the competitiveness of fresh/chilled fish products and dried/salted/smoked fish in the Philippines and Canadian markets was necessary due to the RCA of both fishery products indicated less than one. The competitiveness of frozen fish in the Philippines and Canadian markets was also showed weak competitiveness, followed by the Malaysian market. This finding was consistent with Hidayati's (2016) study which proved that frozen and processed fishery products, especially tuna, tended to possess weak competitiveness in the international market. However, it was necessary to increase the quantity and quality of these three fishery productions for the Singapore, Thailand, and Vietnam markets to avoid a decreased competitiveness.

Fillet and fish meat products showed strong competitiveness in the ASEAN and Canadian markets, except in the Philippines market due to less than one of RCA's value. It was similar to the crustaceans group, except in the Thailand market. For the mollusks group, it was necessary to improve the quality of production to the markets of the Philippines, Singapore, and Thailand. The strongest competitiveness was in the Canadian market, followed by Vietnam and Malaysia.

Based on Table 5, crustaceans and mollusks showed the strongest competitiveness in the Canadian market as these two groups were Indonesia's main export commodities to Canada. Ornamental fish belonged to live fish group was also listed as the primary export commodity of Indonesian fishery products to Canada. These three groups of fishery products had the strongest competitiveness compared to other Indonesian fishery products. This showed that 
Canada was another potential market for Indonesian crustaceans and mollusks group which had been dominated by Malaysia as the largest exporter (Ashari et. al., 2016).

The analysis result also showed that the strength of Indonesian fishery products in ASEAN countries was dominated by fish product with the highest RCA value in the live and fresh/chilled fish products, while crustaceans had the highest competitiveness in Canada. This indicated that Indonesian fishery products were vulnerable to non-tariff barriers imposed by developed countries such as Canada because non-tariff barriers often occur in shrimp commodity (Saptanto et al., 2017).

The market position of Indonesian fishery products in ASEAN and Canada using EPD method can be seen in Table 6. Based on the estimation of EPD results, Indonesian fishery products acquired a rising star market share and export market share from the destination country was lost the opportunity in the Philippines, Thailand, and Canada. The opposite condition occurred in Malaysia, Singapore, and Vietnam markets where Indonesian fishery products lost their falling star market share and no longer wanted by the markets (retreat). Both of these positions were not expected because these indicated that Indonesian fishery products had been declining due to non-dynamic and non-competitiveness movements in global markets (Kusuma \& Firdaus, 2015).

Table 6. EPD estimation of Indonesian fishery products in ASEAN and Canadian Markets

\begin{tabular}{|c|c|c|c|c|c|c|}
\hline Commodity & Malaysia & Philippines & Singapore & Thailand & Vietnam & Canada \\
\hline Live fish & $\begin{array}{l}\text { Falling } \\
\text { star }\end{array}$ & Rising star & Falling star & Rising star & Retreat & Rising star \\
\hline $\begin{array}{l}\text { Fresh/chilled } \\
\text { fish }\end{array}$ & $\begin{array}{l}\text { Falling } \\
\text { star }\end{array}$ & $\begin{array}{c}\text { Lost } \\
\text { opportunity }\end{array}$ & Falling star & Rising star & $\begin{array}{l}\text { Falling } \\
\text { star }\end{array}$ & $\begin{array}{c}\text { Lost } \\
\text { opportunity }\end{array}$ \\
\hline Frozen fish & $\begin{array}{l}\text { Falling } \\
\text { star }\end{array}$ & Rising star & Retreat & Rising star & Retreat & $\begin{array}{c}\text { Lost } \\
\text { opportunity }\end{array}$ \\
\hline $\begin{array}{l}\text { Fillet and fish } \\
\text { meat }\end{array}$ & $\begin{array}{l}\text { Falling } \\
\text { star }\end{array}$ & Rising star & Retreat & Rising star & $\begin{array}{l}\text { Falling } \\
\text { star }\end{array}$ & Rising star \\
\hline $\begin{array}{l}\text { Dried/salted/ } \\
\text { smoked fish }\end{array}$ & $\begin{array}{l}\text { Falling } \\
\text { star }\end{array}$ & Rising star & Falling star & Rising star & Retreat & Rising star \\
\hline Crustaceans & $\begin{array}{l}\text { Falling } \\
\text { star }\end{array}$ & Rising star & Falling star & $\begin{array}{c}\text { Lost } \\
\text { Opportunity }\end{array}$ & Retreat & Rising star \\
\hline Molluscs & $\begin{array}{l}\text { Falling } \\
\text { star }\end{array}$ & Rising star & Falling star & $\begin{array}{c}\text { Lost } \\
\text { Opportunity }\end{array}$ & $\begin{array}{l}\text { Falling } \\
\text { star }\end{array}$ & $\begin{array}{c}\text { Lost } \\
\text { opportunity }\end{array}$ \\
\hline
\end{tabular}

Source: United Nations Commodity Trade, 2017 (processed)

Indonesian live fish and dried/salted/smoked fish had the best benefit (rising star) in the markets of the Philippines, Thailand, and Canada. Live fish products in Malaysia and Singapore were in the falling star position, which showed that Indonesia was unable to meet the growing demand in both countries. Vietnam's market positioned Indonesian live fish and $\mathrm{dried} / \mathrm{salted} / \mathrm{smoked}$ fish products in a retreat condition. This was due to the declining RCA value of these products from 2010 to 2015 . 
A similar condition was also shown by the fillet and fish meat products which grew dynamically in the Philippines, Thailand, and Canada markets. However, it was necessary to improve the product market share in Malaysia and Vietnam markets because fillet and fish meat products of Indonesia was in a falling star position. The more unfavorable condition occurs in the Singapore market where Indonesian fillet and fish meat products were in a stagnancy position and non-competitive (retreat) products.

Indonesian frozen fish had the best competitive benefit in the Philippines and Thailand markets, while the lowest competitive benefit was in the Singapore and Vietnam markets. In the Malaysian market, Indonesian frozen fish was in a falling star position indicating that Indonesia was unable to meet Malaysia's growing demand. Nevertheless, the market share of Indonesian frozen fish in the Canadian market was still increasing in the lost opportunity position. The Indonesian fresh/chilled fish and mollusks groups had a competitive benefit which tended to be better than other fishery products because there was no retreat position in all export destination markets. The consumers desired the export of these products in the primary destination country. The best position for the fresh/chilled fish products was in the Thailand market, while the best position of mollusks group was in the Philippines market.

Table 7. The Market Development Strategy for Indonesian Fishery Products in the ASEAN and Canada Market During 2010-2015

\begin{tabular}{|c|c|c|c|}
\hline Country & Optimistic Market & Potential Market & Less Potential Market \\
\hline Malaysia & - & $\begin{array}{l}\text { Live fish, fresh/chilled fish, fillet } \\
\text { and fish meat, dried/salted/ } \\
\text { smoked fish, crustaceans, molluscs }\end{array}$ & Frozen fish \\
\hline Philippines & Live fish, crustacean & $\begin{array}{l}\text { Frozen fish, fillet and fish meat, } \\
\text { dried/salted/smoked fish, molluscs }\end{array}$ & Fresh/chilled fish \\
\hline Singapore & - & $\begin{array}{l}\text { Live fish, fresh/chilled fish, dried/ } \\
\text { salted/smoked fish, crustaceans }\end{array}$ & $\begin{array}{l}\text { Frozen fish, fillet and } \\
\text { fish meat, molluscs }\end{array}$ \\
\hline Thailand & $\begin{array}{l}\text { Live fish, fresh/chilled } \\
\text { fish, frozen fish, fillet and } \\
\text { fish meat, dried/salted/ } \\
\text { smoked fish }\end{array}$ & - & $\begin{array}{l}\text { Crustaceans and } \\
\text { molluscs }\end{array}$ \\
\hline Vietnam & - & $\begin{array}{l}\text { Fresh/chilled fish, fillet and fish } \\
\text { meat, molluscs }\end{array}$ & $\begin{array}{l}\text { Live fish, frozen fish, } \\
\text { dried/salted/smoked } \\
\text { fish, crustaceans }\end{array}$ \\
\hline Canada & $\begin{array}{l}\text { Live fish, fillet and fish } \\
\text { meat, crustaceans }\end{array}$ & Dried/salted/smoked fish, molluscs & $\begin{array}{l}\text { Fresh/chilled fish, } \\
\text { frozen fish }\end{array}$ \\
\hline
\end{tabular}

The Indonesian most fishery products' market position in the Philippines, Thailand, and Canada showed a rising star position, and the rest of the markets was in the lost opportunity position. Rising star position was the highest position because the commodity was competitive and had a positive trading dynamic. Indonesia gained additional market share in the rapidly growing products. The lost opportunity position was the least desirable position due to opportunity loss created by the declining market share affected by the declining RCA value over the last five years. 
Based on those RCA and EPD, the market development status of Indonesian fishery products in every country presented in Table 7 . The measurement results of the X-model method also showed that Philippines, Thailand, and Canada indicated a positive and potential market development which showed that all three markets had a significant potential to develop Indonesian fishery product market. Indonesian fishery products in Malaysia and Singapore had a potential market development for most commodities, and the rest of it was in the less potential market development. The opposite indicated by the Vietnam market where live, frozen, dried/ salted/smoked fish and crustaceans product were a potential market development for the less potential market. This result because of the competitiveness of Indonesian fishery products was still high compared to Vietnam in the global scope (Natalia \& Nurozy, 2012).

\section{Conclusion}

The results show that during 2010-2015, the export structure of Indonesian fishery products has a similar level to Vietnam and Canada with the ESI value of approaching 1 . This result shows that the competition between Indonesia and those two countries will be higher in the ASEAN market. Research also shows that fishery commodities in HS 4-digit (HS 0301 to HS 0305) have RCA > 1 index which means that strong competitiveness in the export destination markets, except in the Philippines market. Fishery products such as crustaceans and mollusks (HS 0306 and HS 0307) have strong competitiveness in the Canadian, Malaysian, and Vietnamese markets. The analysis results of EPD method show that Indonesian fishery products in the Philippines, Thailand, and Canadian markets are in the rising star position and lost opportunity position, while falling star and retreat position occur in Singapore, Malaysia, and Vietnam markets. The results of X-model analysis of potential export products indicate that Thailand, Philippines, and Canada are optimistic markets for Indonesian fishery products.

Based on the research results, there are several policy implications. First, the Indonesian government and private sectors need to improve the product quality and lower the production costs to boost the competitiveness of fishery products so that Indonesian is able to exploit the potential markets in ASEAN and Canada. Second, the government and private sectors need to prioritize the export of live fish, fresh/chilled fish, frozen fish, fillet and fish meat and also dried/salted/smoked fish to Thailand. Third, the government and private sectors need to prioritize the export markets of Philippines and Canada for live fish, fillet and fish meat, and also crustaceans product.

\section{References}

Ashari, U., Sahara, \& Hartoyo, S. (2016). Daya Saing Udang Segar dan Udang Beku Indonesia di Negara Tujuan Ekspor Utama (Competitiveness of Indonesian Fresh Shrimp and Frozen Shrimp in Major Export Destination Countries). Jurnal Manajemen \& Agribisnis, 13(1), 1-13.

Asmara, A., Purnamadewi, Y. L., Mulatsih, S., \& Novianti, T. (2016). The Alternative Strategy for Strengthening Indonesian Textile and Clothing Industry Structure. Jurnal Bisnis Dan Manajemen, 17(1), 33-47. 
Bender, S., \& Li, K. W. (2002). The Changing Trade and Revealed Comparative Advantages of Asian and Latin American Manufacture Exports. Working Papers No. 843, Economic Growth Center, Yale University.

Chasanah, N., Mulyo, J. H., \& Darwanto, D. H. (2017). Competitiveness and Export Similarity of Indonesian Horticulture in the ASEAN-ASEAN+3. Agro Ekonomi, 28(1), $32-47$.

Estherhuizen. (2006). Measuring and Analyzing Competitiveness in the Agribusiness Sector: Methodological and Analytical Framework. South Africa: University of Pretoria.

Finger, J. M., \& Kreinin, M. E. (1979). A Measure of 'Export Similarity' and Its Possible Uses. The Economic Journal, 89, 905-912.

Hasibuan, A. M., Nurmalina, R., \& Wahyudi, A. (2012). Analisis Kinerja dan Daya Saing Perdagangan Biji Kakao dan Produk Kakao Olahan Indonesia di Pasar Internasional (Analysis of Performance and Competitiveness of Indonesian Cocoa Beans and Processed Cocoa Products in International Markets). Buletin RISTRI, 3(1), 57-70.

Kanaka, S., \& Chinadurai, M. (2012). A Study of Comparative Advantage of Indian Agricultural Exports. Journal of Management and Science, 2(3), 1-9.

Kusuma, R. L., \& Firdaus, M. (2015). Daya Saing dan Faktor yang Mempengaruhi Volume Ekspor Sayuran Indonesia Terhadap Negara Tujuan Utama (Competitiveness and Factors Affecting the Volume of Indonesian Vegetable Exports to Major Destination Countries). Jurnal Manajemen \& Agribisnis, 12(3), 226-236.

Kusumastanto, T. (2008). Kebijakan dan Strategi Peningkatan Daya Saing Produk Perikanan Indonesia (Policies and Strategies for Increasing Competitiveness of Indonesian Fisheries Products). Bogor: Institut Pertanian Bogor.

Natalia, D., \& Nurozy. (2012). Kinerja Daya Saing Produk Perikanan Indonesia di Pasar Global (Competitiveness Performance of Indonesian Fisheries Products in the Global Market). Buletin Ilmiah Litbang Perdagangan, 6(1), 1-10.

Ningsih, E. A., \& Kurniawan, W. (2016). Daya Saing Dinamis Produk Pertanian Indonesia di ASEAN (Dynamic Competitiveness of Indonesian Agricultural Products in ASEAN). Jurnal Ekonomi Kuantitatif Terapan, 9(2), 117-125.

Oktaviani, R., Puspitawati, E., \& Haryadi. (2008). Impacts of ASEAN Agricultural Trade Liberazation on ASEAN-6 Economies and Income Distribution in Indonesia. Asia-Pacific Research and Training Network on Trade Working Papers Series, No. 51.

Saptanto, S. (2011). Daya Saing Ekspor Produk Perikanan Indonesia di Lingkup ASEAN dan ASEAN-China (Indonesian Fisheries Product Export Competitiveness in the ASEAN and ASEAN-China Scope). Jurnal Sosek KP, 6(1), 51-60.

Saptanto, S., Rahadian, R., \& Tajerin. (2017). Dampak Hambatan Non-Tarif terhadap Kinerja Makroekonomi dari Sektor Perikanan dengan Menggunakan Pendekatan Model GTAP (Impact of Non-Tariff Barriers to Macroeconomic Performance from the Fisheries Sector Using the GTAP Model Approach). Jurnal Sosial Ekonomi Kelautan Dan Perikanan, 12(1), 75-91. 
Serin, V., \& Civan, A. (2008). Revealed Comparative Advantage and Competitiveness: A Case Study for Turkey towards the EU. Journal of Economic and Social Research, 10(2), $25-41$.

Suci, S. C., Asmara, A., \& Mulatsih, S. (2015). The Impact of Globalization on Economic Growth in ASEAN. International Journal of Administrative Science and Organization, 22(2), 79-87.

Wang, P. Z., \& Liu, X. J. (2015). Comparative Analysis of Export Simalirity Index between China and EU. In International Conference on Management Science and Management Innovation (MSMI) (pp. 222-227).

Widyastutik, Puspitawati, E., \& Fawaiq, M. (2014). Analisis Dampak Implementasi Komitmen Indonesia di Sektor Jasa Konstruksi dalam Kerangka AFAS (Analysis of the Impact of Implementation of Indonesia's Commitments in the Construction Services Sector in the AFAS Framework). Jurnal Ekonomi Dan Pembangunan Indonesia, 15(1), 41-56.

Zuhdi, F., \& Suharno. (2015). Analisis Daya Saing Ekspor Kopi Indonesia dan Vietnam di Pasar ASEAN 5 (Analysis of Competitiveness of Indonesian and Vietnamese Coffee Exports in the ASEAN Market 5). Habitat, 26(3), 152-162. 